\title{
Students' Perceptions of E-Learning at the University of Jordan
}

\author{
http://dx.doi.org/10.3991/ijet.v9i3.3347 \\ Tamara Almarabeh \\ The University Of Jordan, Amman, Jordan
}

\begin{abstract}
E-learning occupies a high place in universities and academic institutes and it is given the priority by the departments in these educational institutions. What we are witnessing today of the development of information technology and communications, networks, and multimedia is pushing us in the direction of the adoption of E-learning in education. The purpose of this study is to examine students' perception of E-learning at the University of Jordan based on Technology Acceptance Model. The results of the study show that the students are highly qualified and accepting the E-learning system with the desire to use it in more advanced manner.
\end{abstract}

Index Terms-E-learning, Jordan, Technology Acceptance Model, Perceived usefulness, Perceived ease of use.

\section{INTRODUCTION}

The traditional teaching process changed after adopting the development of Information, multimedia technology, and using the internet as a new way of teaching [1]. Also the learning environment and scenarios changed by using electronic media such as internet, audio, videoconferencing, interactive TV and satellite as medium to conduct Elearning [2].

The development of the educational process in all countries of the world is a prominent goal and a large strive which can be achieved through development of policies, continuous programs, and substantial investments to improve the quality of education. The information and communication technology revolution is one of the largest promising catalysts for developing countries to promote their educational systems and access to the ranks of developed countries in education. It is argued that the achieved outcomes from the traditional education and training programs are quite often far from ideal [3], so the institutions have to find a new way of learning and developing a new system to manage the flow of knowledge [4].

E-learning has been defined according to the contexts and environments where it operates [5]. Multiple definitions of E-learning introduced in this paper. One of these definitions, is the use of Information and Communication Technology e.g. Internet, Computer, Mobile phone, Learning Management System (LMS), Televisions, Radios and others to enhance teaching and learning activities. Other researchers [6] defined E-learning is a unifying term used to describe the fields of online learning, web-based training and technology delivered instructions. Jenkins and Hanson indicated that E-learning facilitated and supported the learning process through information and communication technologies (ICTs) [7]. Maslin [8] used simple terms to define E-learning in "when we use infor- mation and communication technologies (ICTs) for knowledge seeking or delivering we refer this method as E-learning".

There is a substantial growth in the use of E-learning platforms in higher education from universities around the world [9]. But, within the Middle East educational system, the E-learning system is still in its infancy phases [10].

Usually, new systems fail because the end users do not accept to use. Either because they do not see any benefits from using these systems or they see these systems too complex which cause a lot of troubles for them. Elearning system is one of these new systems that can be accepted or rejected by end users. According to Ozkan and Koseler [11], E-learning systems are multidisciplinary, where the success of E-learning depends on two factors:

- Technological factor, i.e. software and hardware that are used to build E-learning system.

- Human factor, i.e. students and instructors.

In this research paper, the researcher used TAM model to measure the student's acceptance of MOODLE as Elearning system in the University of Jordan. This paper is organized as follows: section II, E-learning in Jordan, section III, theoretical framework, section IV the research methodology with hypotheses and measures, Discussion and analysis in section V. Finally, the conclusion and future work in section VI.

\section{E-LEARNING IN JORDAN}

The objective of E-learning is to embed technology integration through the creation of 21 st century learning environments where traditional assessment criteria and expectations are exceeded, where the learning is the key point of any strategic plan. To make this real; the technology must be available at all times and functional to support all educational objectives [12]. The demand for Elearning in Jordan is expected to rise in the next few years [13]. Large expenditure and substantial effort has been made by the Ministry of Education in Jordan to successfully implement E-learning developments in schools [14]. While the higher education system has rapidly expanded, it has not yet produced a sufficient qualitative leap [15]. Reflecting the world's University sector moving forward with E-learning, Jordanians higher education institutions are responding accordingly. E-learning offers alternative approaches to Jordanian traditional higher education institutions, encouraging them to re-evaluate the way they operate. In doing so, it provides potential to accommodate new information and communication technologies to enhance the student learning experience [13]. The Ministry 
of Higher Education and Scientific Research (MoHESR) has formed an E-learning steering committee to draft a national E-learning strategy with a mission: "To support institutions of higher education in their move towards embedding eLearning appropriately using technology to transform education into a learner centric system that is internationally distinguished in its quality and impact, to foster innovation and excellence in teaching and learning, and to support employability of lifelong learning".

E-learning was first introduced in Jordan by the Arab Open University (AOU) [16]. The Arab Open University (AOU) - Jordan Branch (http://www.aou.edu.jo) was established in 2002. The E-learning system adopted by this university is blended E-learning not distance. This university uses technical media, including printed materials, radio and television broadcasts, video and audio cassettes and CDROMs, computer-based learning and multimedia labs and telecommunications. AOU uses Learning Management System (LMS) to manage and provide the learning teaching activities. The university is using MOODLE as E-learning system for online exams, student authentication to its grades, teacher authentication to its contents (such as module description, student's names, and student's grades), E-salaries, E-attendance, latest news about the courses.

The University of Jordan established in 1962. It has 19 faculties 2 deanships and 15 centers in the main campus in Amman in addition to 5 faculties in Aqaba branch. The University of Jordan (UJ) (http://www.ju.edu.jo) was using Blackboard as E-learning platform to provide better service to students and teachers, to facilitate accessing the required material from anywhere, and to facilitate the communication between them. Blackboard has been used in UJ mainly to design a well formed virtual learning environment (VLE) which facilitates the interaction among all parties in the teaching process, students and teachers. From the academic year 2012/2013 the UJ is starting to use MOODLE instead of Blackboard as a main learning management system LMS, but the using still in the beginning, for example: the teacher can upload the module description, assignments, latest news about the courses. The students can check these announcements, download the assignments. The LMS can be accessed by registered users from anywhere in the world using Internet and web browsers. The web-based communication tools have given the online education a new edge [17]. A study [18] reviewed the status of E-learning in Jordan in SWOT model showed that Jordan has sufficient awareness of the importance of E-learning, the factors that help in the success and the challenges of such project and explained that the implementation process is gradual and needs patience, encouragement, and continuous technical support.

\section{THEORETICAL FRAMEWORK}

There are many theories of technology acceptance used to appreciate the perceptions of students. One of such models is developed by Davis (1989) called the Technology Acceptance Model (TAM) as shown in Fig. 1. As indicated in many researches [19], [20]. TAM was built based on Theory of Reasoned Action (TRA) upon Fishbein and Ajzen's (1975) which posits that beliefs could influence attitudes (feelings of favorableness or unfavorableness towards using the technology), which lead to intention to use (indicates the strength on one's intentions to use the technology in the future), and finally actu-

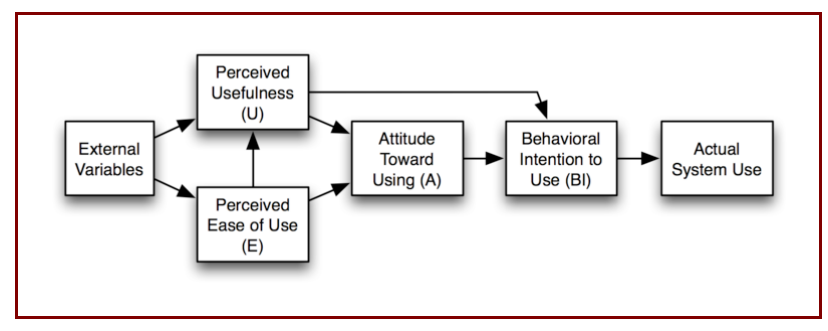

Figure 1. Original Technology Acceptance Model (TAM)

al usage behavior. TAM describes that a person's behavioral intention to use E-learning is determined by perceived usefulness and perceived ease of use [21]. The Technology Acceptance Model (TAM) has been widely used in explaining IT adoption and usage.

TAM has been applied in various studies for testing user acceptance of information technology, for example, word processors, spreadsheet applications, e-mail, web browser, telemedicine, and blackboard [22]-[27]. In this study, the MOODLE is considered an E-learning system that makes use of Internet and web technology to deliver information to and interact with the students through a computer interface.

The TAM model suggests that when users are presented with a new technology, a number of factors influence their decision about how and when they will use it, notably [28]:

- Perceived usefulness (PU) - This was defined by Fred Davis as "the degree to which a person believes that using a particular system would enhance his or her job performance".

- Perceived ease-of-use (PEOU) - Davis defined this as "the degree to which a person believes that using a particular system would be free from effort".

The research hypotheses based on TAM model of Elearning system are:

- H1: Perceived ease of use has a significant influence on the university of Jordan students' perceived usefulness.

- H2: Perceived ease of use has a significant influence on the university of Jordan students' attitude towards using.

- H3: Perceived usefulness has a significant influence on the university of Jordan students' attitude towards using.

- H4: Perceived usefulness has a significant influence on the university of Jordan students' behavioral intention to use.

- H5: Attitude towards using has a significant influence on the university of Jordan students' behavioral intention to use.

\section{RESEARCH MeTHODOLOGY}

\section{A. Sample}

The data in this study was gathered via survey distributed to 180 students from different faculties (medical, scientific, and humanitarian) registered in 2 courses, Remedial Computer Skills and Computer Skills for Humanities, in the fall semester 2013/2014 at the University of Jordan. The questions divided in 2 groups, the first group contains 3 questions including the student's age, academic year, 
and the faculty. The second group contains 16 questions divided to 4 questions for PEOU, 4 questions for PU, 3 questions for ATU and 5 questions for ITU. The second group questions used a 5-point Likert scale (strongly agree, agree, neutral, disagree, and strongly disagree) to measure students' response. These questions are adopted from previous information system research [8], [29] [31]. Fig. 2 shows the research model employed in this study. It is a reduced TAM model, excluding actual system use.

\section{B. Measures}

Measurement validity in terms of reliability and construct validity was evaluated. The reliability analysis measured the internal validity and consistency of questions used for each construct by calculating Cronbach's alpha coefficient [32]. Flynn et al. [33] argued that a Cronbach's alpha of 0.6 and above was considered an effective reliability for judging a scale. The generally agreed lower limit for Cronbach's alpha may decrease to 0.60 in exploratory research [34]. In the survey used in this study, the Cronbach's alpha was higher than 0.6 as shown in Table I which implies that the instrument is reliable.

To examine construct validity of measures, a factor analysis was adopted in this study. Four factors were requested, based on the fact that the questions were designed to index four constructs: perceived ease of use (PEOU), perceived usefulness (PU), and attitude toward using (ATU) and intention to use (ITU). All factor loadings were above 0.5 , showing good convergent validity [35] as shown in Table II.

The results revealed the test was an established instrument with high reliability and validity scores.

\section{DISCUSSION AND RESULTS}

The research model shown in Fig. 2 was tested using Minitab Software. In testing the hypotheses the researcher used a regression analyses based on 180 completed surveys collected for this study. Using a hypothesis approach, all the hypotheses are supported as shown in Table III and Table IV.

In linear regression matrix there are five parameters, $\mathrm{R}^{2}$ (the coefficient of the correlation or the relation) which shows the strength and direction of the relationship. PValue indicates the significant of the relationship, $\mathrm{P}$ must always equal or less than 0.05 for the relationship to be significant. Beta, $\beta$ which is another parameter in linear regression shows the slope and the direction of the relationship, standard error of $\beta$ indicates the percentage of error that can happen. The smaller the standard error of $\beta$ the less likely error can happen while $t$ statistics is the coefficient divided by its error.

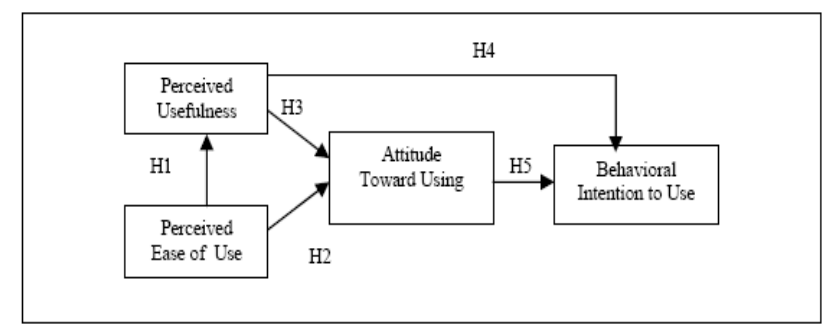

Figure 2. The research model
TABLE I.

CRONBACH'S ALPHA

\begin{tabular}{|l|c|c|}
\hline Item & Number of Items & Cronbach's Alpha \\
\hline Perceived Ease of Use & 4 & 0.807 \\
\hline Perceived Usefulness & 4 & 0.700 \\
\hline Attitudes Toward Usage & 3 & 0.806 \\
\hline Intension To Use & 5 & 0.673 \\
\hline Total & 16 & 0.840 \\
\hline
\end{tabular}

TABLE II.

FACTOR ANALYSIS

\begin{tabular}{|l|c|c|c|c|}
\hline Item & Factor 1 & Factor 2 & Factor 3 & Factor 4 \\
\hline PEOU1 & 0.838 & & & \\
\hline PEOU2 & 0.824 & & & \\
\hline PEOU3 & 0.764 & & & \\
\hline PEOU4 & 0.764 & & & \\
\hline PU1 & & 0.682 & & \\
\hline PU2 & & 0.731 & & \\
\hline PU3 & & 0.722 & & \\
\hline PU4 & & 0.812 & & \\
\hline ATU1 & & & 0.811 & \\
\hline ATU2 & & & 0.860 & \\
\hline ATU3 & & & 0.855 & \\
\hline ITU1 & & & & 0.740 \\
\hline ITU2 & & & & 0.766 \\
\hline ITU3 & & & & 0.779 \\
\hline ITU4 & & & & 0.589 \\
\hline ITU5 & & & & 0.540 \\
\hline Factor 1: Perceived Ease of Use (PEOU), Factor 2: Perceived Usefulness (PU), Factor 3: Atti-
\end{tabular}

tude towards Using (ATU), and Factor 4: Behavior Intention to Use (ITU)

TABLE III.

REGRESSION RESULTS FOR THE HYPOTHESES

\begin{tabular}{|l|c|c|c|c|c|l|}
\hline $\begin{array}{l}\text { Independent } \\
\text { Variable }\end{array}$ & $\boldsymbol{\beta}$ & $\mathbf{S E}$ & $\mathbf{T}$ & $\mathbf{P}$ & $\mathbf{R}^{2}$ & $\begin{array}{l}\text { Dependent } \\
\text { Variable }\end{array}$ \\
\hline $\begin{array}{l}\text { perceived ease } \\
\text { of use }\end{array}$ & 0.462 & 0.06 & 7.37 & 0.000 & 0.23 & $\begin{array}{l}\text { perceived use- } \\
\text { fulness }\end{array}$ \\
\hline $\begin{array}{l}\text { perceived ease } \\
\text { of use }\end{array}$ & 0.283 & 0.06 & 5.00 & 0.000 & 0.12 & $\begin{array}{l}\text { attitude towards } \\
\text { using }\end{array}$ \\
\hline $\begin{array}{l}\text { perceived } \\
\text { usefulness }\end{array}$ & 0.409 & 0.06 & 7.36 & 0.000 & 0.23 & $\begin{array}{l}\text { attitude towards } \\
\text { using }\end{array}$ \\
\hline $\begin{array}{l}\text { perceived } \\
\text { usefulness }\end{array}$ & 0.302 & 0.09 & 3.40 & 0.001 & 0.06 & $\begin{array}{l}\text { behavioral } \\
\text { intention to use }\end{array}$ \\
\hline $\begin{array}{l}\text { attitude to- } \\
\text { wards using }\end{array}$ & 0.645 & 0.10 & 6.66 & 0.000 & 0.20 & $\begin{array}{l}\text { behavioral } \\
\text { intention to use }\end{array}$ \\
\hline
\end{tabular}

TABLE IV.

SUMMARY OF HYPOTHESES TESTING

\begin{tabular}{|c|l|c|}
\hline Hypothesis & \multicolumn{1}{|c|}{ Relationship Tested } & Results \\
\hline H1 & $\begin{array}{l}\text { Perceived ease of use has a significant influ- } \\
\text { ence on the university of Jordan students' } \\
\text { perceived usefulness. }\end{array}$ & Supported \\
\hline H2 & $\begin{array}{l}\text { Perceived ease of use has a significant influ- } \\
\text { ence on the university of Jordan students' } \\
\text { attitude towards using. }\end{array}$ & Supported \\
\hline H3 & $\begin{array}{l}\text { Perceived usefulness has a significant influ- } \\
\text { ence on the university of Jordan students' } \\
\text { attitude towards using. }\end{array}$ & Supported \\
\hline H4 & $\begin{array}{l}\text { Perceived usefulness has a significant influ- } \\
\text { ence on the university of Jordan students' } \\
\text { behavioral intention to use. }\end{array}$ & Supported \\
\hline H5 & $\begin{array}{l}\text { Attitude towards using has a significant influ- } \\
\text { ence on the university of Jordan students' } \\
\text { behavioral intention to use. }\end{array}$ & Supported \\
\hline
\end{tabular}


As you see in Table III and Table IV, the perceived usefulness (PU) and attitude towards using (ATU) are influenced by perceived ease of use (PEOU) $\left(\mathrm{R}^{2}=0.23, \beta=\right.$ $0.462),\left(\mathrm{R}^{2}=0.12, \beta=0.283\right)$ same as in other studies [22], [36]. The perceived usefulness (PU) has a significant influence $\left(\mathrm{R}^{2}=0.23, \beta=0.409\right)$ on the attitudes towards using (ATU) better than its influence on behavioral intention to use (ITU). This may be due to the fact that students are willing to adopt E-learning systems, while focusing on its benefits. Some researchers [37], [38] found that an attitude towards using (ATU) is a direct determinant of behavioral intention to use (ITU) and this is what the researcher found it in this study.

\section{CONCLUSION AND FUTURE WORK}

This work indicated that TAM can be employed as a useful theoretical base to predict and understand users' intentions to use E-learning. The findings of this study demonstrate some interesting issues. First, the students of the University of Jordan are highly qualified to use Elearning system and have sufficient awareness of benefits of this system. Second, the results revealed that the perceived usefulness and perceived ease of use are factors that directly affect students' attitudes toward using Elearning system, whereas the perceived usefulness is the strongest and most significant determinant of students' attitude towards using.

The author suggests some recommendations for future work. First, the study didn't test a full TAM, where the actual technology use wasn't included in the research model, so the researcher will add the actual use to examine the whole TAM model. Second, the researcher will examine the TAM model with the teachers from the University of Jordan to get more comprehensive view of perception the E-learning system.

\section{REFERENCES}

[1] Tao, Y. H., Yeh, C. R., \& Sun, S. I. (2006). Improving training needs assessment processes via the Internet: system design and qualitative study. Internet Research, 16(4), 427-49. http://dx.doi.org/10.1108/10662240610690043

[2] Hung, H., \& Cho, V. (2008). Continued usage of E-learning communication tools: a study from the learners' perspective in Hong Kong. International Journal of Training and Development, 12, 171-187. http://dx.doi.org/10.1111/j.1468-2419.2008.00302.x

[3] Chen, R. S., \& Hsiang, C. H. (2007). A study on the critical success factors for corporations embarking on knowledge community-based E-learning. Information Sciences, 177 2, 570-586. http://dx.doi.org/10.1016/j.ins.2006.06.005

[4] Liu,Y., \& Wang, H. (2009). A comparative study on E-learning technologies and products: from the East to the West. Systems Research \& Behavioral Science, 26(2), 191-209. http://dx.doi.org/10.1002/sres.959

[5] Asabere, N. and Enguah, S. (2012). "Use of Information \& Communication Technology (ICT) in Tertiary Education in Ghana: A Case Study of Electronic Learning (E-learning)". International Journal of Information and Communication Technology Research. 2(1), pp.62-68.

[6] Oye, N. D., Salleh, M., \& Iahad, N. A. (2010). Holistic Elearning in Nigerian Higher Education Institutions. Journal of Computing, 2(11), 20-26.

[7] Jenkins, M. \& Hanson, J. (2003). E-learning series: A guide for senior managers, Learning and Teaching Support Network (LSTN) Generic Centre, United Kingdom.

[8] Masrom, M. (2007).Technology Acceptance Model and Elearning 12th International Conference on Education.

[9] Paechter, M. Maier, B. \& Macher, D. (2010). Students' expectations of and experiences in E-learning: their relation to learning achievements and course satisfaction. Computers \& Education, 54(1), 222-229. http://dx.doi.org/10.1016/j.compedu.2009.08.005

[10] Ali, G.,\& Magalhaes, R., (2008). Barriers to implementing Elearning: a Kuwaiti case study. International Journal of Training and Development. 12(1), 36-5 http://dx.doi.org/10.1111/j.14682419.2007.00294.x

[11] Ozkan, S. \& Koseler, R. (2009). Multi-dimensional students evaluation of e learning systems in the higher education context: An empirical investigation. Computers \& Education (53) p. 12851296. http://dx.doi.org/10.1016/j.compedu.2009.06.011

[12] Al-Shboul, M., Rababah O., (2013), "A Vision to Improve Elearning at The University of Jordan". World Applied Sciences Journal, 21 (6): 902-914.

[13] Al-Adwan, A. and J. Smedley, 2012. "Implementing E-learning in the Jordanian Higher Education System: Factors Affecting Impact". International Journal of Education and Development using Information and Communication Technology, 8(1): 121-135.

[14] Alomari, A., 2009. Investigating Online Learning Environments in a Web-Based Math Course in Jordan. International Journal of Education and Development using Information and Communication Technology, 5(3): 19-36.

[15] Sabri, H. and G. El-Refae, 2006. Accreditation in Higher Business Education in the Private Sector: The Case of Jordan. Journal of Marketing for Higher Education, 16(1): 47-76. http://dx.doi.org/10.1300/J050v16n01_03

[16] Abbad, M., Morris, D. \& De Nahlik, C. (2009). "Looking under the Bonnet: Factors Affecting Student Adoption of E-learning Systems in Jordan". International Review of Research in Open and Distance Learning, 10(2), pp. 1-24.

[17] Ardi, M. (2008). Teachers' Perceptions of Teaching with Computer Technology: Reasons for Use and Barriers in Usage. International Journal of Instructional Technology and Distance Learning. Vol. 5. No. 6.

[18] Almarabeh T., Mohammad H., "E-learning in the Jordanian Higher Education System: Strengths, Weakness, Opportunities, and Threats (2013)", Journal of American Science 2013;9(3).

[19] Pituch, K \& Lee, Y-K. (2006). The influence of system characteristics on E-learning use. Computers and Education, 47, 222-244. http://dx.doi.org/10.1016/j.compedu.2004.10.007

[20] Hayashi, A., Chen, C., Ryan, T \& Wu, J. (2008). The role of social presence and moderating role of computer self efficacy in predicting the continuance usage of E-learning systems. Journal of Information Systems Education, 15, 2, 139-148

[21] Mahdizadeh, H., Biemans, H \& Mulder, M. (2008). Determining factors of the use of E-learning environments by university teachers. Computers \& Education, 51, 142-154 http://dx.doi.org/10.1016/j.compedu.2007.04.004

[22] Davis, F.D. (1989). Perceived usefulness, perceived ease of use and user acceptance of information technology. MIS Quarterly, 13(3), 319-339. http://dx.doi.org/10.2307/249008

[23] Mathieson, K. (1991). Predicting user intentions:comparing the technology acceptance model with theory of planned behavior. Infromation Systems Research, 2(3), 173-191. http://dx.doi.org/10.1287/isre.2.3.173

[24] Szajna, B. (1996). Empirical evaluation of the revised technology acceptance model. Management Science, 42(1), 85-92. http://dx.doi.org/10.1287/mnsc.42.1.85

[25] Morris, M.G., \& Dillon, A. (1997). The influence of user perceptions on software utilization: application and evaluation of a theoretical model of technology acceptance, IEEE Software, 14(4), 5675.

[26] Hu, P.J., Chau, P.Y.K., Sheng, O.R.L., \& Tam, K.Y. (1999). Examining the technology acceptance model using physical acceptance of telemedicine technology. Journal of Management Information Systems, 16(2), 91-112.

[27] Landry, B.J.L., Griffith, R. , \& Hartman, S. (2006). Measuring student perceptions of blackboard using the technology acceptance model. Decision Sciences, 4(1), 87-99.

[28] Wikipedia, http://en.wikipedia.org/wiki/Technology_acceptance_model (accessed 1/10/2013)

[29] Malhotra, Y. \& Galletta, D. (1999). "Extending the Technology Acceptance Model to Account for Social Influence: Theoretical 
PAPER

STUdENTS' PERCEPTIONS OF E-LEARNING AT THE UNIVERSITY OF JORDAN

Bases and Empirical Validation". Proceedings of the 32nd Hawaii International Conference on system Sciences, 1, pp.1006.

[30] Kripanont, N. (2007). "Examining a Technology Acceptance Model of Internet Usage by Academics within Thai Business Schools".

[31] Sek, Y., Lau, S., Teoh, K. \& Law, C. (2010). "Prediction of User Acceptance and Adoption of Smart Phone for Learning with Technology Acceptance Model”. Journal of Applied Sciences, 10 (20), pp. 2395-2402. http://dx.doi.org/10.3923/jas.2010.2395.2402

[32] Moolla, A. \& Bisschoff, C. (2012). "Validating a Model to Measure the Brand Loyalty of Fast Moving Consumer Goods". J. Soc Sci, 31 (2), pp.101-115.

[33] Flynn, B., Schroeder, R., \& Sakakibara, S. (1994). A framework for quality management research and an associated measurement instrument. Journal of Operations Management, 11, 339-366. http://dx.doi.org/10.1016/S0272-6963(97)90004-8

[34] Hair, J., Black, W. C., Babin, B. J., \& Anderson, R. E. (2010). Multivariate data analysis (7th ed.). Upper saddle River, New Jersey: Pearson Education International.

[35] Chesney, T. (2006). An acceptance model for useful and fun information systems. Human Technology, 2(2), 225-235.

[36] Shroff, R., Deneen, C. \& Ng, D. (2011). "Analysis of the technology acceptance model in examining students' behavioral intention to use an e-portfolio system". Australasian Journal of Educational Technology, 27 (4), pp.600-618.

[37] S. Liu, H. Liao, and J.A. Pratt (2009). Impact of media richness and flow on E-learning technology acceptance. Computers \& Education, vol. 52, pp. 599-607. http://dx.doi.org/10.1016/ j.compedu.2008.11.002

[38] Lee, M.K., Cheung C.M., and Chen Z. (2005). Acceptance of Internet-based learning medium: the role of extrinsic and intrinsic motivation. Information \& Management, vol. 42, pp. 1095- 1104. http://dx.doi.org/10.1016/j.im.2003.10.007

\section{AUTHOR}

Tamara Almarabeh received the master degree in computer science from the University of Jordan. Currently, is working as teacher with the Department of Computer Information Systems, The University of Jordan, Amman, CO 11942 Jordan (e-mail: t.almaraabeh@ju.edu.jo). Her research interests include E-business, E-government, and E-learning.

Submitted 13 November 2014. Published as re-submitted by the author 18 May 2014. 